\title{
Article \\ Off-Farm Employment and Economic Crisis: Evidence from Cyprus
}

\author{
Elias Giannakis ${ }^{1, *}$, Sophia Efstratoglou ${ }^{2}$ and Artemis Antoniades ${ }^{3}$ \\ 1 Energy, Environment and Water Research Center, The Cyprus Institute, 20 Konstantinou Kavafi Street, \\ 2121 Nicosia, Cyprus \\ 2 Department of Agricultural Economics and Rural Development, Agricultural University of Athens, \\ 75 Iera Odos, 11855 Athens, Greece; sefst@aua.gr \\ 3 Department of Agriculture, Ministry of Agriculture, Rural Development and Environment, Louki Akrita, \\ 1412 Nicosia, Cyprus; mantoniades@da.moa.gov.cy \\ * Correspondence: e.giannakis@cyi.ac.cy; Tel.: +357-22-208683
}

Received: 24 January 2018; Accepted: 12 March 2018; Published: 15 March 2018

\begin{abstract}
Off-farm employment is an important strategy for complementing farm household income and maintaining rural livelihoods. A multilevel logistic regression model was applied to investigate the effect of farm-level and regional-level factors on off-farm employment in Cyprus during the recent economic crisis period. The performance of nonfarm sectors positively affects off-farm employment; a one-percent increase in the share of the secondary and tertiary sector employment increases the likelihood of off-farm work by 9.5 times. The importance of location was also identified. Farm households located in rural areas are $70 \%$ less likely to engage in off-farm work than households located in urban areas. The positive effect of educational attainment and the negative effect of farm training confirmed the importance of human capital characteristics on off-farm labour participation. Farm structural factors are also significant determinants of off-farm employment. A one-hectare increase in the farm size decreases the odds of off-farm labour participation by $50 \%$. Operators of crop farming holdings are 4.2 times more likely to work off the farm than operators of livestock and mixed-farming holdings. The results reveal the importance of adopting a multilevel and integrated approach for the analysis of off-farm employment.
\end{abstract}

Keywords: off-farm employment; economic crisis; multilevel modelling; logistic regression model; contextual effects; education; farm size; farm type; Cyprus

\section{Introduction}

European rural regions have been undergoing significant structural changes. The successive Common Agricultural Policy (CAP) reforms, the international trade liberalisation, and the rapid growth of nonagricultural sectors have created new opportunities and challenges for the European countryside. Agriculture is no longer the backbone of most rural economies, and is neither necessary nor sufficient for generating and maintaining high income and employment shares in rural areas [1]. Emerging sectors, including the food manufacturing industry and tourism sector, create strong backward and forward linkages in many rural communities, complementing and/or replacing agriculture in this role [2]. A less protective framework for agriculture, including a reduction in CAP subsidies, may further push farmers to search for other forms of stable income or to leave agriculture [3].

Engaging in off-farm employment has been considered an important strategy for maintaining rural livelihoods through the stabilization of the farm household income [1]. Several studies have showed that off-farm employment is complementary to farm work and slows down the exit from agriculture $[4,5]$. Conversely, other studies support that off-farm employment fosters the structural change in agriculture [6]. 
The first wave of studies exploring off-farm work, and more broadly 'pluriactivity', emerged during the 1980s and 1990s [7-9]. Off-farm diversification was later discussed in periods of agricultural policy reforms, e.g., the decoupling of subsidies from production $[10,11]$. However, the study of off-farm employment during economic downturn periods is limited. Understanding the factors affecting farmers' off-farm labour decisions during recessionary periods has significant implications for agricultural and rural development policy.

Over the last decade, European countries and regions have experienced a period of severe economic downturn [12]. Cyprus, along with Greece and Spain, experienced the largest losses in employment and economic output among European countries (Figure 1). More precisely, Cyprus entered into recession in 2012, and its economic output was reduced for three consecutive years (2012-2014) with a total loss of $10.3 \%$, while the total loss of employment was also around $10 \%$. During this period, the unemployment rate almost doubled, from $7.9 \%$ in 2011 to $16.1 \%$ in 2014 [13]. The greatest job losses were observed in the construction sector and the services sector, resulting in declining opportunities for off-farm employment.

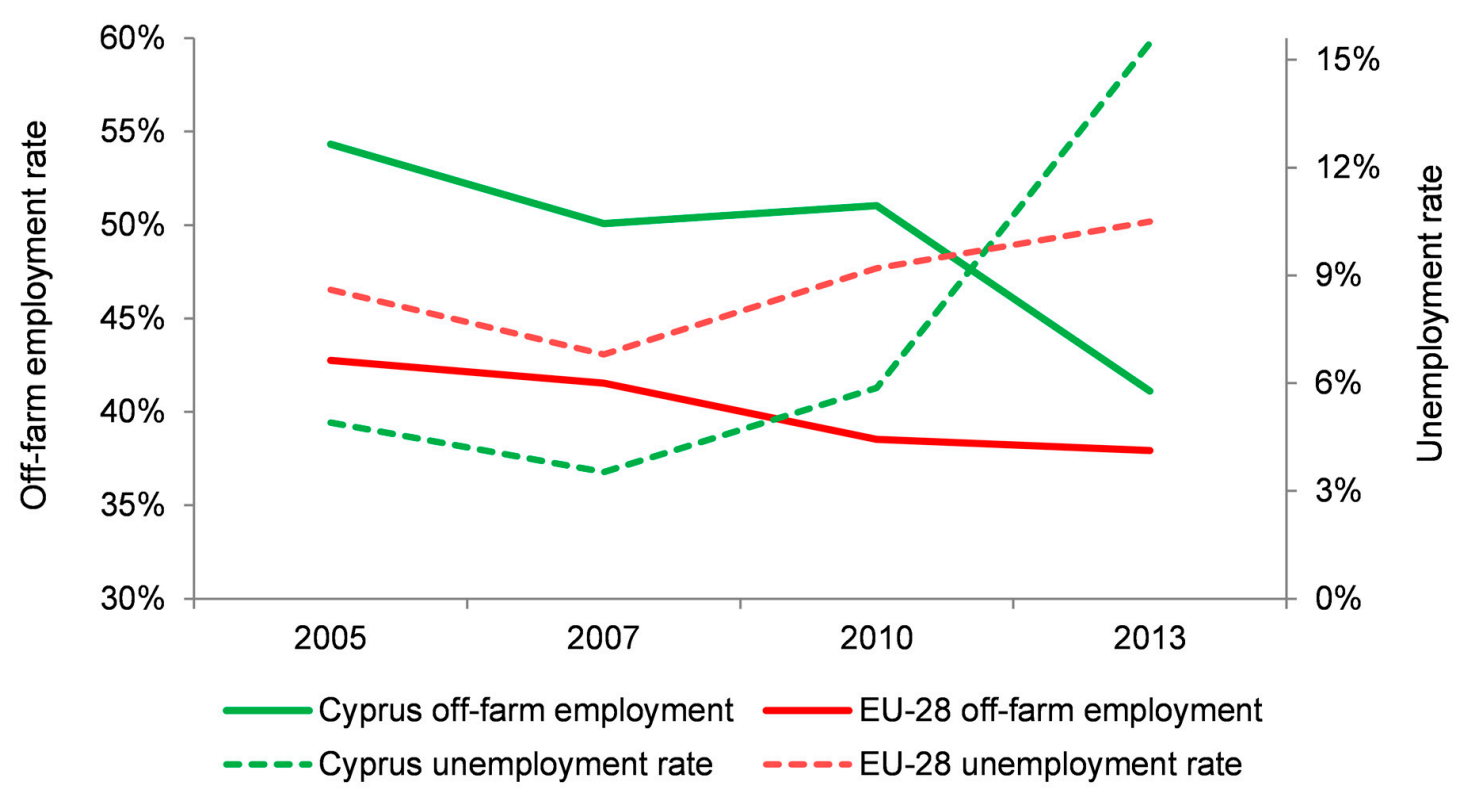

Figure 1. Cyprus and European Union (EU)-28 off-farm employment and unemployment rates, 2005-2013. Sources: European Commission [14]; Eurostat [15].

The engagement of farmers in other gainful activities in the European Union (EU)-28 was reduced from $42 \%$ to $38 \%$ between 2007 and 2013, i.e., the period of economic crisis in Europe. Before the economic downturn, around half of Cypriot farmers were engaged in gainful activities other than farm work. From 2010 to 2013, i.e., the recession period in Cyprus, the share of 'pluriactive' farmers declined from $51 \%$ to $41 \%$. At the member state level, Bulgaria and Sweden registered the highest share of farmers being engaged in off-farm employment (73\%) in 2013, while Belgium had the lowest share (13\%).

This paper aims to analyse the factors affecting the off-farm labour decisions of Cypriot farmers, using a representative survey of 193 farmers. We aim to contribute to the off-farm employment literature along two main directions. First, we examine the effects of individual, farm household, and farm holding characteristics (microlevel) and location (spatial-level) on farmers' engagement in off-farm work during the recent economic crisis. Second, we assess the magnitude of contextual effects on off-farm employment in Cyprus. 


\section{Conceptual Framework}

Several studies of off-farm employment have focused on the factors affecting participation in the off-farm labour supply (e.g., $[1,16])$. Off-farm labour decisions by the principal farm operator are affected by individual, farm household, farm holding, social capital, and spatial characteristics [1].

\subsection{Individual Characteristics}

Human capital characteristics, i.e., age and education, significantly affect the farmer's decision to allocate his/her work in off-farm activities. Several studies have showed that younger farmers are more likely to work off the farm [1,17]. Higher education levels have been positively associated with higher off-farm wages, implying greater willingness to seek off-farm employment $[1,18]$. On the other hand, higher education may increase the productivity of farm work, thus discouraging off-farm participation [19]. Farm training typically raises the earning capacity of the farm business, and therefore usually implies reduced willingness for off-farm employment [20].

\subsection{Farm Household Characteristics}

The size of the farm household can be an important factor for motivating participation in nonfarm labour markets. Having more family members increases the need for additional income that is expected to be positively related to off-farm activities [10,16]. Additionally, a larger household can more easily divide on-farm work than a smaller one, thus releasing some of the family members to work off-farm [3]. Farm succession can also influence off-farm labour decisions, as it affects the structure of farm holdings, thus providing the incentive to develop and expand farm activities over long periods [21]. The availability of a successor within the farm family is directly linked with farm survival [22].

\subsection{Farm Holding Characteristics}

Farm size, expressed in physical, labour, or economic output units, is expected to affect off-farm labour decisions. Larger farms, as measured in any way, typically require more labour on the farm, thus resulting in fewer hours available for off-farm work $[1,10,17]$. The type of farming operation, i.e., crop farming, animal farming, and mixed farming, affect the engagement of farm operators in off-farm employment; labour-intensive farming, e.g., livestock operations, requires a constant presence of the operator on the farm, compared with less-intensive types of farming, e.g., field and permanent cropping [1,17].

\subsection{Social Capital}

The social capital in agriculture, defined as the shared knowledge and trust embodied in the relationships between farmers, can be an important determinant of off-farm employment [23]. It is usually expressed by farmers' memberships of organizations, participation in social networks, and access to information and knowledge. Farmers' participation in rural development policy schemes is expected to negatively affect the participation of farm operators in nonfarm labour markets, as they commit themselves to maintaining farming for a specific period of time.

\subsection{Spatial Features}

Farmers' participation in off-farm labour markets is affected not only by their willingness and ability to supply labour, but also by the demand for this labour [24]. Spatial features, including the accessibility and the availability of employment, affect farmers' likelihood to work off the farm. The location of farm households can capture the geographic heterogeneity and the urbanization effect. Sparsely populated areas are less business-intensive with fewer off-farm employment opportunities than areas with high population densities [3,18]. Local labour market characteristics shape the propensity of farmers to work off the farm. It is expected that multiple job-holding, i.e., farm and 
nonfarm, will be more prevalent in locations where there is significant employment in the secondary and tertiary sectors $[1,25]$. In locations where local labour markets operate inefficiently or the demand for labour outside agriculture is low, it is expected that off-farm labour will be less prevalent [1,17]. The performance of the local labour markets is typically reflected in the unemployment rate of the community in which the farm household is located [1].

\subsection{Analytical Methods}

Farmers' decisions for off-farm labour are significantly affected by regional-level and farm-level factors. Multilevel modelling is suitable when data are hierarchically structured, i.e., consisting of units grouped at different levels of a hierarchy [26]. Multilevel regression models are being increasingly applied in regional labour market studies [12] and rural development studies [27].

\section{Data and Methodology}

\subsection{Data Collection}

The farm household survey was implemented between January and May 2013 in the five districts of Cyprus, namely, Lefkosia, Lemesos, Larnaka, Pafos, and Ammochostos. Farm households were identified in each district through census data [28]; a sample of 200 farm households, that is, $0.5 \%$ of the total number of farm households in Cyprus, was randomly selected across the five districts. The distribution of the surveyed farm households by district and rural/urban areas is presented in Figure 2. The definition of rural/urban areas in Cyprus follows the regional typology definition of the Organisation for Economic Co-operation and Development (OECD) [29], which is based on the population density criterion. For more details on the definition of rural areas in Cyprus, see Giannakis [30].

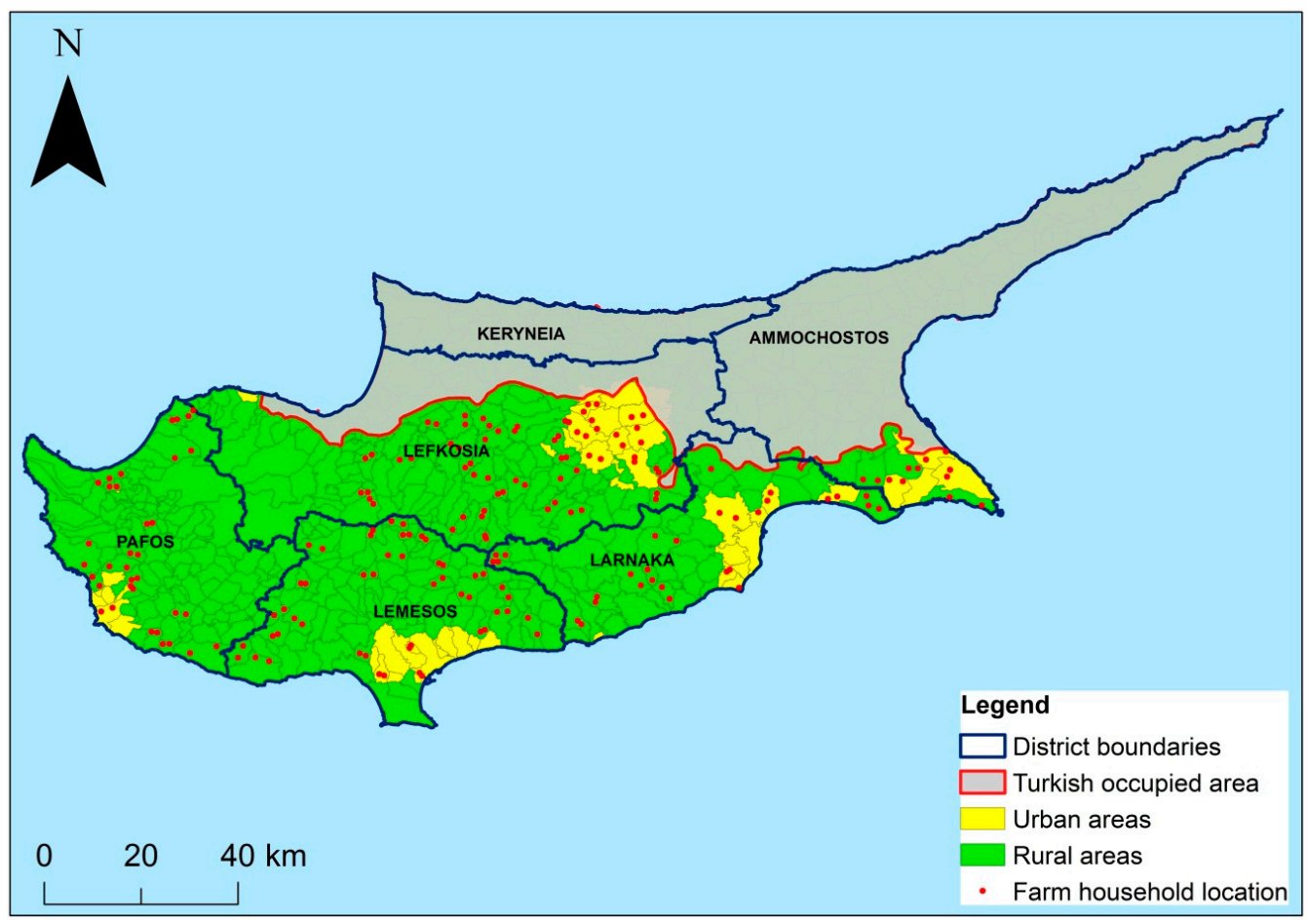

Figure 2. Distribution of surveyed farm households by district and rural/urban areas.

Face-to-face interviews were conducted with the farm operators, i.e., those responsible for making farming decisions. Farmers were contacted and informed of the study, and those that agreed to participate in the survey were subsequently interviewed. As a result of the face-to-face household 
visit survey mode used in this study, the response rate was high (96.5\%), i.e., of the 200 farm operators contacted, 193 farmers were interviewed, thus yielding in 193 completed questionnaires. Table 1 presents the farm holdings in Cyprus and the surveyed farm households by district.

Table 1. Farm holdings in Cyprus and surveyed farm households by district.

\begin{tabular}{ccccc}
\hline Districts of Cyprus & \multicolumn{2}{c}{ Cyprus } & \multicolumn{2}{c}{ Survey Sample } \\
\hline & Number & Percent (\%) & Number & Percent (\%) \\
Lefkosia & 13,592 & 35.0 & 67 & 34.7 \\
Lemesos & 10,144 & 26.1 & 50 & 25.9 \\
Larnaka & 5816 & 15.0 & 29 & 15.0 \\
Pafos & 6926 & 17.8 & 35 & 18.1 \\
Ammochostos & 2381 & 6.1 & 12 & 6.2 \\
Total & 38,859 & 100 & 193 & 100 \\
\hline \multicolumn{5}{c}{ Source: CYSTAT [28]; survey data. }
\end{tabular}

\subsection{Questionnaire Design and Sample Description}

The questionnaire was designed by the authors after a thorough review of previous research and taking into account the farm structures of Cyprus [31,32]. More precisely, the questionnaire gathered data on five main topics: (a) socio-demographic characteristics of the farm household members (age, education, number of household members); (b) employment status of the farm operator (employment on- and off-farm, days of employment); (c) structural characteristics of the farm holding (farm size, ownership, composition of farm, and livestock production); (d) social capital (sources of information and membership in associations); and (e) knowledge and participation in rural development programme measures. These data were supplemented by community-/municipality-level sectoral employment and unemployment data from the Statistical Service of Cyprus. The questionnaire was pilot-tested with 10 farmers on an individual basis. Based on the results of the pilot testing, several individual questions were slightly rephrased and/or reordered.

Sixty-three percent of the surveyed farm operators were full-time employed in farm activities, while $37 \%$ were engaged in off-farm employment. The nonfarm sectors in which farmers were most engaged were construction ( $28 \%)$, trade $(10 \%)$, and transportation $(10 \%)$. About $60 \%$ of the 'pluriactive' farmers worked off the farm for 180-220 days, thirty percent worked off the farm for more than 220 days, while only ten percent worked off-farm for fewer than 180 days. The highest shares of farmers engaged in off-farm employment were observed in Lefkosia (40\%), i.e., the capital of the island, and Lemesos (42\%), while the lowest was observed in Ammochostos district (25\%).

The average size of the sampled farm holdings was $1 \mathrm{ha}$, of which on average $24 \%$ was irrigated. National surveys suggest a higher average farm size in Cyprus, that is, 3 ha, of which $29 \%$ is irrigated. The main cultivations grown on the sampled farms include cereals, olive trees, vineyards, potatoes, and vegetables, while livestock mainly includes sheep and goats, and to a lesser extent beef and dairy cattle.

\subsection{Variables}

Within this study, the decision of a farm operator to participate in off-farm employment is a function of both level-1 (farm-level) and level-2 (regional-level) explanatory variables. Farm-level variables include individual characteristics (age, education, gender, farm training), farm household characteristics (number of household members, succession), farm holding characteristics (farm size, type of farming), social capital-related factors (membership in farm union, sources of technical advice), and policy-related factors (participation in rural development programmes). Regional-level variables include the location of the farm household in rural or urban communities and the structure of the local labour markets (share of nonagricultural employment, unemployment). The definitions and descriptive statistics of all predictor variables used in the analysis are shown in Table 2. 
Table 2. Description of the explanatory variables used in the multilevel logistic regression model and key summary statistics for the 193 surveyed farmers in Cyprus.

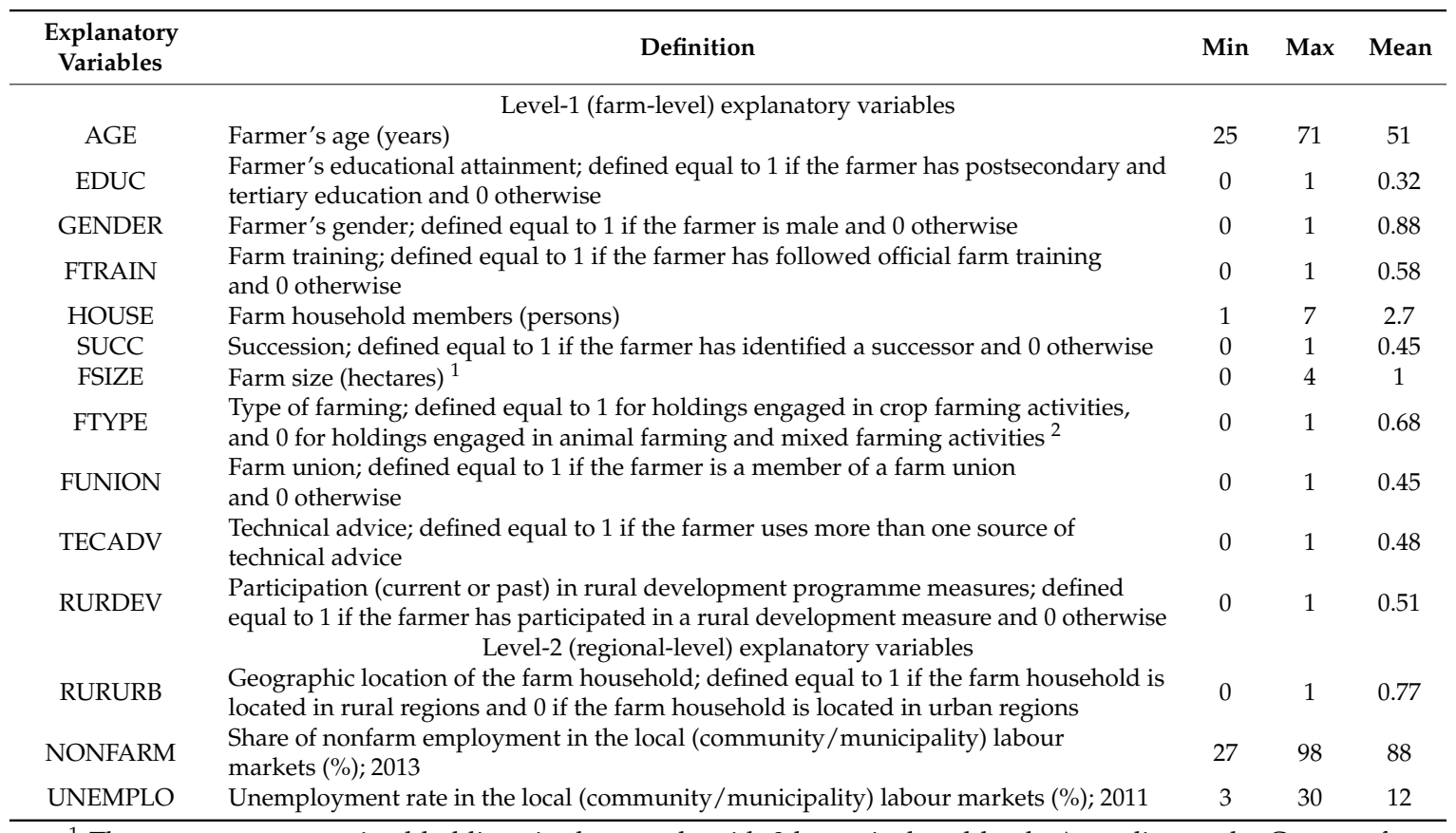

${ }^{1}$ There are two pure animal holdings in the sample with 0 ha agricultural land. According to the Census of Agriculture 2010, 1.4\% of the farm holdings in Cyprus are pure animal holdings, of which $92 \%$ are with no agricultural land. ${ }^{2}$ One dummy variable was used to reflect farm typology; considering that the share of pure animal holdings in the total number of farms is minor, that is, $1 \%$, pure animal holdings were merged with mixed farming holdings in one category.

\subsection{Methodology}

The empirical framework of the study is based on a multilevel model that distinguishes two levels of analysis, i.e., the farm-level and the regional-level. More specifically, farmers' decision-making process is nested within regional-level data and can be formalised as a discrete choice model.

Assuming that for the dichotomous choice of engaging or non-engaging in off-farm work $\left(y_{i j}\right)$, there is a continuous latent variable $\left(y_{i j}^{*}\right)$ that is related to $\left(y_{i j}\right)$ as follows:

$$
y_{i j}=\left\{\begin{array}{l}
1 \text { if } y_{i j}^{*} \geq 0 \\
0 \text { if } y_{i j}^{*}<0
\end{array}\right.
$$

A two-level random intercept model can be applied in terms of a latent response variable $\left(y_{i j}^{*}\right)$ as follows:

$$
y_{i j}^{*}=\beta_{0}+\beta_{1} x_{i j}+u_{j}+e_{i j}^{*}
$$

where $x_{i j}$ is a set of 14 covariates, i.e., farmer characteristics, farm holding characteristics, spatial factors, and others; and $e_{i j}^{*}$ is the farm (level-1) residual and $u_{j}$ is the regional (level-2) residual. The total variance is partitioned into the regional-level residual variance $\left(\sigma_{u}^{2}\right)$ and the farm-level residual variance $\left(\sigma_{e}^{2}\right)$ [33]. The variance partition coefficient (VPC) measures the proportion of the residual variability in off-farm employment that is attributed to between-communities variation, and is given by the following formula [34]:

$$
V P C=\frac{\sigma_{u}^{2}}{\sigma_{u}^{2}+\sigma_{e}^{2}}
$$

The farm-level residual $\left(e_{i j}^{*}\right)$ is assumed to be distributed as a standard logistic distribution with variance equal to $\pi^{2} / 3$, that is, 3.29 [34]. 
Odds ratios are used in the analysis of the results as the coefficients of the random intercept logistic regression model indicate the direction of the effect, but do not provide any evidence about the size [26]. The variance inflation factor (VIF) was used to test and quantify the severity of multicollinearity of the explanatory variables of the model. All calculations were done in STATA 12 (StataCorp, College Station, TX, USA) econometric software package.

\section{Results}

We estimate two specifications of the multilevel logistic regression model (Table 3): (a) with only level-1 variables (model 1); (b) including both level-1 and level-2 variables (model-2). We observe that the odds ratios of the level-1 variables do not change significantly after including level-2 variables in the model, thus suggesting that farm and farmer characteristics have a robust effect on farmers' engagement in off-farm employment. The variance partition component (VPC) of the model, which reflects the between-group variance, reduces from 0.526 to 0.301 when regional variables are included, thus highlighting the importance of including level-2 variables in the model. More precisely, the VPC indicates that $30.1 \%$ of the variance in the probability of a farmer to work off the farm is attributable to unobserved regional features.

Table 3. Multilevel logistic regression odds ratios and significance of farm-level and regional-level determinants of off-farm employment.

\begin{tabular}{|c|c|c|c|c|c|c|}
\hline \multirow[t]{3}{*}{ Explanatory Variables } & \multicolumn{3}{|c|}{ Model 1} & \multicolumn{3}{|c|}{ Model 2} \\
\hline & Odds Ratio & Std. Error & $p$ & Odds Ratio & Std. Error & $p$ \\
\hline & \multicolumn{6}{|c|}{ Level-1 (farm-level) explanatory variables } \\
\hline AGE & 0.95 & 0.04 & 0.183 & 0.96 & 0.04 & 0.282 \\
\hline EDUC & 3.09 & 1.98 & 0.078 & 3.11 & 1.90 & 0.063 \\
\hline GENDER & 0.72 & 0.56 & 0.677 & 0.52 & 0.40 & 0.402 \\
\hline FTRAIN & 0.23 & 0.14 & 0.012 & 0.38 & 0.22 & 0.097 \\
\hline HOUSE & 1.78 & 0.36 & 0.004 & 1.80 & 0.37 & 0.004 \\
\hline SUCC & 1.28 & 0.70 & 0.652 & 1.22 & 0.66 & 0.709 \\
\hline FSIZE & 0.51 & 0.16 & 0.035 & 0.50 & 0.16 & 0.034 \\
\hline FTYPE & 4.25 & 2.69 & 0.022 & 4.21 & 2.66 & 0.023 \\
\hline FUNION & 0.85 & 0.49 & 0.782 & 1.03 & 0.57 & 0.950 \\
\hline TECADV & 2.52 & 1.49 & 0.117 & 2.47 & 1.46 & 0.124 \\
\hline RURDEV & 0.49 & 0.27 & 0.193 & 0.47 & 0.25 & 0.165 \\
\hline \multicolumn{7}{|c|}{ Level-2 (regional-level) explanatory variables } \\
\hline RURURB & & & & 0.30 & 0.21 & 0.086 \\
\hline NONFARM & & & & 9.52 & 7.72 & 0.005 \\
\hline UNEMPLO & & & & 0.83 & 0.50 & 0.751 \\
\hline Constant & 1.29 & 3.19 & 0.917 & 1.27 & 3.16 & 0.923 \\
\hline \multicolumn{7}{|c|}{ Between-group variance } \\
\hline Var(cons) & 3.65 & 2.58 & 0.004 & 1.42 & 0.89 & 0.034 \\
\hline Observations & & 193 & & & 193 & \\
\hline Log-likelihood & & -91.8 & & & -82.5 & \\
\hline p-value & & 0.009 & & & 0.022 & \\
\hline $\mathrm{VPC}$ & & 0.526 & & & 0.301 & \\
\hline
\end{tabular}

The odds for farmers with postsecondary and tertiary education (EDUC) to participate in off-farm work are 3.1 times greater than farmers with a lower level of education. On the contrary, farm training (FTRAIN) is negatively associated with off-farm employment; i.e., trained farmers are $62 \%$ less likely to work off the farm than farmers with practical experience only. We note that the larger the farm household size (HOUSE), the higher the likelihood of off-farm labour participation; an increase in the household size by one person increases the likelihood of working off-farm by $80 \%$.

When looking at the farm holding characteristics, we find that farm size (FSIZE) is negatively associated with the decision of operators to work off the farm, i.e., a one-hectare increase decreases 
the odds of off-farm labour participation by $50 \%$. The type of farming (FTYPE) is also a significant determinant for off-farm employment. Operators of crop farming holdings have a 4.2-times higher probability to work off-farm than operators of livestock and mixed-farming holdings. With regard to explanatory variables concerning social capital and participation in rural policy support schemes, we find no significant effects on off-farm employment.

Farm households located in rural areas (RURURB) are 70\% less likely to engage in off-farm work than households located in urban areas. The share of nonfarm employment in the local labour markets (NONFARM) has the greatest positive effect in the likelihood of off-farm labour participation. More precisely, an increase in the share of secondary and tertiary employment by $1 \%$ increases the odds of off-farm work by 9.5 times. The negative effect of unemployment in off-farm work is not statistically significant.

\section{Discussion}

The findings of the analysis highlight the magnitude of regional features, i.e., contextual effects, on the off-farm labour decision process. Farm households located in rural areas are less likely to work off the farm. Chang and Yen [18] found that farm households located in the urban and town areas of Taiwan are more likely to work off the farm, compared to households located in villages. Similar urbanization effects on off-farm employment are reported for Dutch farmers living close to large cities [3]. Wu et al. [35] found that urbanization in California, Idaho, Oregon, and Washington is associated with higher production costs compared to rural localities, which are however outweighed by higher prices for agricultural products and increased off-farm job opportunities, thus resulting in net farm income increases.

The outcomes of the analysis underline the importance of the presence of the nonagricultural economic sectors. Chang and Boisvert [25] found that farm operators engaging in labour markets that depend on manufacturing jobs are more likely to work off the farm. Similarly, Alasia et al. [1] reported that both manufacturing and services employment have a positive impact on the likelihood of off-farm labour participation. Our farm household survey in Cyprus revealed that the main reasons for farmers to work off the farm were: (a) increase of household income (44\%) and (b) opportunities and prospects in the nonfarm labour market (19\%). Lemesos (42\%) and Lefkosia (40\%) are the districts with the highest share of farm operators engaged in off-farm employment, which can be partially attributed to the rapid development of the services sector [32]. On the contrary, Ammochostos district has the lowest share of farmers working off the farm $(25 \%)$, which can be attributed to the dynamic and export-oriented local agricultural sector (e.g., potato cultivation).

Apart from the regional features, our model results suggest that human capital and in particular education are major determinants for off-farm labour participation. Alasia et al. [1] explored the off-farm labour decisions of Canadian farm operators, and found a positive association between educational attainment and off-farm work. Our findings highlight the negative effect of farm training on the engagement in off-farm work. Weiss [20] investigated the off-farm labour market behaviour of Upper Austrian farm households, and found that the transition of a farm operator from the lowest to the next level of farm education decreases the likelihood of off-farm work by $1.65 \%$. Farm training improves the knowledge and skills of farmers, fosters the adoption of new technologies, and positively contributes to the economic performance of the agricultural sector [36,37]. Our analysis shows that the size of the farm household positively affects the participation in off-farm work. Van Leeuwen and Dekkers [3] found a positive association between the farm household size and the off-farm income in the Netherlands; one extra household member was related to $4 \%$ more off-farm income.

Farm size seems to negatively affect the likelihood of off-farm labour participation. Alasia et al. [1] found that for the Canadian operators of both smaller and larger holdings, there is an inverse and significant relationship between farm size and off-farm employment. Conversely, Biørn and Bjørnsen [17] analysed the labour market transitions of Norwegian farm households, and found that the larger the farm area, the higher the off-farm labour participation. Our findings suggest that 
operators of holdings solely engaged in crop farming activities are more likely to work off the farm. Biørn and Bjørnsen [17] found a negative association of livestock and off-farm participation in Norway. Alasia et al. [1] reported a negative relationship between dairy farming and off-farm employment in Canada, while van Leeuwen and Dekkers [3] found a positive association of dairy farming and arable farming with off-farm income in the Netherlands.

The results of our analysis did not indicate a statistically significant relationship between unemployment and off-farm work, even though the farm household survey was conducted during the recent economic crisis that severely hit the economy of Cyprus. A possible explanation could be the nonsignificant variance of unemployment across communities, which reflects high labour mobility among local labour markets. Future research could incorporate time-series information to better understand off-farm labour decisions during economic crisis and economic growth periods.

Regional context is highly affected by policies implemented at the spatial level. Among them, rural development policy is a key 'place-based' policy to promote the diversification of economic activities in European rural areas [38]. The evolution and the subsequent reforms of the Common Agricultural Policy have allocated additional resources for rural development to stimulate rural employment; that is, jobs located in rural areas, but not necessarily linked with the production of agricultural goods. Regional policies also encourage the development of small- and medium-sized enterprises in rural areas to diversify their economic base [39]. The integration of rural development policy with regional and cohesion policies in a common strategic framework can further enhance their capacity to invigorate rural employment [40].

\section{Conclusions}

The results of the study indicate that the operation of large scale farming, farm training, engagement in animal farming, and the location of farm households in rural areas impede the participation of farmers in off-farm employment. Our findings reveal that the structure of the local labour markets, i.e., the share and the performance of the industry and the services sector, is the factor with the highest impact on off-farm employment. The significance and the magnitude of the determinants of off-farm employment are strongly affected by contextual effects, which reinforce the need of adopting an integrated and multilevel approach for the analysis of this complex issue. A better harmonisation of rural development policies with regional policies can further enhance the economic diversification of rural areas and the associated off-farm employment opportunities.

Acknowledgments: The authors would like to thank the three anonymous reviewers for their constructive comments and suggestions that greatly improved the final version of the article.

Author Contributions: S.E., A.A., and E.G. contributed to the design of the study and the survey. A.A. and E.G. contributed to the collection of the data. E.G. analysed the data and wrote the paper with support from all coauthors.

Conflicts of Interest: The authors declare no conflict of interest.

\section{References}

1. Alasia, A.; Weersink, A.; Bollman, R.; Cranfield, J. Off-farm labour decision of Canadian farm operators: Urbanization effects and rural labour market linkages. J. Rural Stud. 2009, 25, 12-24. [CrossRef]

2. Giannakis, E.; Bruggeman, A. Economic crisis and regional resilience: Evidence from Greece. Pap. Reg. Sci. 2017, 96, 451-476. [CrossRef]

3. Leeuwen, E.V.; Dekkers, J. Determinants of off-farm income and its local patterns: A spatial microsimulation of Dutch farmers. J. Rural Stud. 2013, 31, 55-66. [CrossRef]

4. Kimhi, A.; Bollman, R. Family farm dynamics in Canada and Israel: The case of farm exits. Agric. Econ. 1999, 21, 69-79. [CrossRef]

5. Breustedt, G.; Glauben, T. Driving forces behind exiting from farming in Western Europe. J. Agric. Econ. 2007, 58, 115-127. [CrossRef]

6. Weiss, C. Farm growth and survival: Econometric evidence for individual farms in Upper Austria. Am. J. Agric. Econ. 1999, 81, 103-116. [CrossRef] 
7. Huffman, W. Farm and off-farm work decisions: The role of human capital. Rev. Econ. Stat. 1980, 62, 14-23. [CrossRef]

8. Efstratoglou-Todoulou, S. Pluriactivity in different socio-economic contexts: A test of the push-pull hypothesis in Greek farming. J. Rural Stud. 1990, 6, 407-413. [CrossRef]

9. Evans, N.; Llbery, B. The pluriactivity, part-time farming, and farm diversification debate. Environ. Plan. A 1993, 25, 945-959. [CrossRef]

10. Serra, T.; Goodwin, B.; Featherstone, A. Agricultural policy reform and off-farm labour decisions. J. Agric. Econ. 2005, 56, 271-285. [CrossRef]

11. Corsi, A.; Salvioni, C. Once part-timer always part-timer? Causes for persistence in off farm work state of farmers. Bio-Based Appl. Econ. 2017, 6, 159-182.

12. Giannakis, E.; Bruggeman, A. Determinants of regional resilience to economic crisis: A European perspective. Eur. Plan. Stud. 2017, 25, 1394-1415. [CrossRef]

13. Giannakis, E.; Mamuneas, T. Sectoral linkages and economic crisis: An input-output analysis of the Cypriot economy. Cyprus Econ. Policy Rev. 2018, in press.

14. European Commission. Farmers with Other Gainful Activity. Rural Development in the European Union-Statistical and Economic Information 2007-2013; EC: Brussels, Belgium, 2016.

15. Eurostat. Unemployment by Sex and Age-Annual Average [une_rt_a]. 2016. Available online: http: / /appsso.eurostat.ec.europa.eu/nui/show.do?dataset=une_rt_a\&lang=en (accessed on 20 December 2016).

16. Sumner, D.A. The off-farm labor supply of farmers. Am. J. Agric. Econ. 1982, 64, 499-509. [CrossRef]

17. Biørn, E.; Bjørnsen, H. What motivates farm couples to seek off-farm labour? A logit analysis of job transitions. Eur. Rev. Agric. Econ. 2015, 42, 339-365. [CrossRef]

18. Chang, H.; Yen, S. Off-farm employment and food expenditures at home and away from home. Eur. Rev. Agric. Econ. 2010, 37, 523-551. [CrossRef]

19. Corsi, A.; Salvioni, C. Off-and on-farm labour participation in Italian farm households. Appl. Econ. 2012, 44, 2517-2526. [CrossRef]

20. Weiss, C. Do they come back again? The symmetry and reversibility of off-farm employment. Eur. Rev. Agric. Econ. 1997, 24, 65-84. [CrossRef]

21. Potter, C.; Lobley, M. The farm family life cycle, succession paths and environmental change in Britain's countryside. J. Agric. Econ. 1996, 47, 172-190. [CrossRef]

22. Bertoni, D.; Cavicchioli, D. Farm succession, occupational choice and farm adaptation at the rural-urban interface: The case of Italian horticultural farms. Land Use Policy 2016, 57, 739-748. [CrossRef]

23. Meert, H.; Huylenbroeck, G.V.; Vernimmen, T.; Bourgeois, M.; Hecke, E.V. Farm household survival strategies and diversification on marginal farms. J. Rural Stud. 2005, 21, 81-97. [CrossRef]

24. Lass, D.; Findeis, J.; Hallberg, M. Factors affecting the supply of off-farm labor: A review of empirical evidence. In Multiple Job-Holding among Farm Families; Iowa State University Press: Ames, IA, USA, 2011; pp. 23-262.

25. Chang, H.; Boisvert, R. Does Participation in the Conservation Reserve Program and/or Off-Farm Work Affect the Level and Distribution of Farm Household Income? Working Paper 2009-34; Department of Applied Economics and Management Cornell University: New York, NY, USA, 2009.

26. Gelman, A.; Hill, J. Data Analysis Using Regression and Multilevel/Hierarchical Models, 1st ed.; Cambridge University Press: New York, NY, USA, 2006.

27. Pascucci, S.; de-Magistris, T.; Dries, L.; Adinolfi, F.; Capitanio, F. Participation of Italian farmers in rural development policy. Eur. Rev. Agric. Econ. 2013, 40, 605-631. [CrossRef]

28. The Statistical Service of Cyprus (CYSTAT). Census of Agriculture 2010; Statistical Service of Cyprus: Nicosia, Cyprus, 2016.

29. Organisation for Economic Co-operation and Development (OECD). Creating Rural Indicators for Shaping Territorial Policy; OECD: Paris, France, 1994.

30. Giannakis, E. The role of rural tourism on the development of rural areas: The case of Cyprus. Roman. J. Reg. Sci. 2014, 8, 38-53.

31. Antoniades, A.; Papayiannis, C. Part-Time Farming in Cyprus; Agricultural Economics Report 40; Agricultural Research Institute, Ministry of Agriculture, Natural Resources and Environment: Nicosia, Cyprus, 2001; ISSN 0379-0827. 
32. Antoniades, A. Pluriactivity in Agriculture and Differentiation of Rural Areas in Cyprus. Ph.D. Thesis, Department of Agricultural Economics and Rural Development, Agricultural University of Athens, Athens, Greece, 2013. (In Greek)

33. Browne, W.; Subramanian, S.; Jones, K.; Goldstein, H. Variance partitioning in multilevel logistic models that exhibit overdispersion. J. R. Stat. Soc. Ser. A (Stat. Soc.) 2005, 168, 599-613. [CrossRef]

34. Goldstein, H.; Browne, W.; Rasbash, J. Partitioning variation in multilevel models. Underst. Stat. 2002, 1, 223-231. [CrossRef]

35. Wu, J.; Fisher, M.; Pascual, U. Urbanization and the viability of local agricultural economies. Land Econ. 2011, 87, 109-125. [CrossRef]

36. Giannakis, E.; Bruggeman, A. The highly variable economic performance of European agriculture. Land Use Policy 2015, 45, 26-35. [CrossRef]

37. Giannakis, E.; Bruggeman, A.; Djuma, H.; Kozyra, J.; Hammer, J. Water pricing and irrigation across Europe: Opportunities and constraints for adopting irrigation scheduling decision support systems. Water Sci. Technol. Water Supply 2016, 16, 245-252. [CrossRef]

38. European Commission. Regulation (EU) No 1305/2013 of the European Parliament and of the Council on support for rural development by the European Agricultural Fund for Rural Development (EAFRD) and repealing Council Regulation (EC) No 1698/2005. Off. J. Eur. Union 2013, L347, 487-548.

39. Matthews, A. On and Off Farm Diversification: The Policy Framework. In Proceedings of the Policy Workshops on Rural Development, Curragh, Ireland, 25 February 2004.

40. Crescenzi, R.; de Filippis, F.; Pierangeli, F. In tandem for cohesion? Synergies and conflicts between regional and agricultural policies of the European Union. Reg. Stud. 2015, 49, 681-704. [CrossRef]

(C) 2018 by the authors. Licensee MDPI, Basel, Switzerland. This article is an open access article distributed under the terms and conditions of the Creative Commons Attribution (CC BY) license (http:/ / creativecommons.org/licenses/by/4.0/). 